\title{
Separation and Pre-concentration of Cadmium, Copper, Lead, Nickel and Zinc by Solid-Liquid Extraction of their Cocrystallized Naphthalene Dithizone Chelate in Saline Matrices
}

\author{
Antônio C. Spínola Costa ${ }^{*, a}$, Leila Lopes ${ }^{a, b}$, Maria das Graças A. Korn ${ }^{a}$ and Jicarla G. Portela ${ }^{a}$ \\ ${ }^{a}$ Instituto de Química, Universidade Federal da Bahia, Campus Universitário de Ondina, 40170-290 \\ Salvador - BA, Brazil \\ ${ }^{b}$ PETROBRAS, Salvador, Bahia 41856-900, Brazil
}

\begin{abstract}
Um procedimento em batelada é proposto para separação e pré-concentração de cádmio, chumbo, níquel e zinco em amostras de salmoura. O método baseia-se na adsorção dos íons metálicos sobre a fase sólida composta de ditizona co-cristalizada com naftaleno microcristalino, na faixa de $\mathrm{pH}$ de 8,5-9,1. Ácido nítrico é utilizado para re-extrair os cátions da fase sólida, os quais são determinados por ICP-OES. Vários parâmetros, tais como efeito do $\mathrm{pH}$, do tempo de agitação e da quantidade da fase sólida foram estudados sistematicamente visando otimizar as condições para a determinação de quantidades traço de $\mathrm{Cd}, \mathrm{Cu}, \mathrm{Pb}, \mathrm{Ni}$ e $\mathrm{Zn}$ em amostras sintéticas de salmoura. Os limites de detecção obtidos, expressos em $\mu \mathrm{g} \mathrm{L}^{-1}$, foram: $44(\mathrm{Zn}), 11(\mathrm{Ni}), 30(\mathrm{Cd}), 47(\mathrm{~Pb})$ e $11(\mathrm{Cu})$. A precisão do procedimento foi estabelecida pela medida de 10 replicatas com $250 \mu \mathrm{g} \mathrm{L}^{-1}$ de cada íon e os desvios padrão relativos foram de 2,71\%(Cd), 2,15\% (Cu), 1,53\% (Pb), 2,47\% (Ni) e 2,78\% (Zn). A exatidão do procedimento foi confirmada pelo método de adição de analitos e os resultados obtidos indicaram recuperação quantitativa $(\geq 95 \%)$.
\end{abstract}

A procedure for separation and pre-concentration of trace amounts of cadmium, copper, lead, nickel, and zinc in brine samples has been proposed. It is based on the adsorption of metal ions onto dithizone co-crystallized with microcrystalline naphthalene, in the $\mathrm{pH}$ range 8.5-9.1. Nitric acid is used to back-extract the cations from the solid phase, which are measured by ICP-OES. Various parameters, such as the effect of $\mathrm{pH}$, stirring time, and amounts of solid phase, have been studied in detail, to optimize the conditions for the determination of trace amounts of $\mathrm{Cd}, \mathrm{Cu}, \mathrm{Pb}, \mathrm{Ni}$ and $\mathrm{Zn}$ in synthetic brine samples. The limits of detection values expressed in $\mu \mathrm{g} \mathrm{L}^{-1}$ are 44 (Zn), 11 (Ni), 30 $(\mathrm{Cd}), 47(\mathrm{~Pb})$ and $11(\mathrm{Cu})$. The precision of the procedure was determined by running 10 replicate samples, each one containing $250 \mu \mathrm{g} \mathrm{L}^{-1}$ of each element and the relative standard deviations were $2.71 \%(\mathrm{Cd}), 2.15 \%(\mathrm{Cu}), 1.53 \%(\mathrm{~Pb}), 2.47 \%(\mathrm{Ni})$, and $2.78 \%(\mathrm{Zn})$. The accuracy of the procedure was confirmed by applying the analyte additions method and the results indicated that quantitative recoveries $(\geq 95 \%)$ were obtained.

Keywords: preconcentration, solid-liquid extraction, naphthalene, dithizone, highly saline matrices

\section{Introduction}

The direct determination of metals in highly saline matrices by atomic spectrometry is difficult because the aspiration of solutions with high salt concentrations into the plasma or flame can cause problems such as blockage of the nebulizer, considerable background emission, transport and chemical interferences, with consequent drop in sensitivity and precision. For industrial application of brine $(\mathrm{NaCl} 20-30 \% \mathrm{~m} / \mathrm{v})$, the usual concentration of trace metals require limits of detection quite difficult to be

* e-mail:pgquim@ufba.br reached by direct determination of samples using inductively coupled plasma optical flame emission spectrometry (ICP-OES) or flame atomic absorption spectrometry (FAAS) techniques. Therefore, separation and pre-concentration methods have played fundamental role in solving these problems. ${ }^{1,2}$

Many separation and pre-concentration techniques for determination of metal ions have been proposed. Solidliquid separation after adsorption of metal chelates on cocrystallized microcrystalline naphthalene is faster and more straightforward than traditional methods. In addition, it can be applied to several types of metal complexes. ${ }^{3-15}$ Recently, a pre-concentration method for $\mathrm{Zn}$ was 
developed using 2-(5-bromo-2-piridylazo)-5diethylaminophenol ${ }^{4}$ and 1-(2-pyridylazo)-2-naphthol ${ }^{5}$ supported on microcrystalline naphthalene. In other work, Taher ${ }^{6}$ used atomic absorption spectrometric method for determination of trace amounts of nickel in alloys and biological samples after pre-concentration with the ion pair of 2-(5-bromo-2-piridylazo)-5-diethylaminophenol and ammonium tetraphenylborate on microcrystalline naphthalene. Therefore, the referred works have a limited applicability once the analytical methods proposed for separation and pre-concentration are suitable for a single element.

Dithizone has two active hydrogen atoms that can be substituted by a cation. It is a $\mathrm{S}, \mathrm{N}$ binder donor that reacts with "soft" cations like Mn, Fe, Co, Ni, Cu, Zn, Pd, Ag, Cd, In, $\mathrm{Sn}, \mathrm{Pt}, \mathrm{Au}, \mathrm{Hg}, \mathrm{Ti}, \mathrm{Pb}, \mathrm{Bi}, \mathrm{Se}, \mathrm{Te}$ and Po. The nonpolar dithizonates formed are slightly soluble in water and soluble in organic solvents. Liquid-liquid extraction and spectrophotometric determination of metals using dithizone are sensitive, but have low selectivity and both reagent and complexes are unstable. ${ }^{16-19}$

In the present paper we describe a pre-concentration method that allows in a single operation five metallic cations to be separated from brine samples. The separation and pre-concentration are performed using dithizone supported on naphthalene. The sorbed elements are subsequently eluted with nitric acid and determined by ICP-OES.

\section{Experimental}

\section{Reagents}

All reagents were of analytical reagent grade. Metals stock solutions were prepared from Merck standard solutions to a final concentration of $1.000 \mathrm{~g} \mathrm{~L}^{-1}$. Work solutions were daily prepared by diluting aliquots with pure water and acidified with nitric acid. Buffer solutions were glycine/hydrochloric acid adjusted at $\mathrm{pH} 3$, acetate buffer at $\mathrm{pH} 4$ to 6 , tris- $\mathrm{HCl}$ buffer at $\mathrm{pH} 7$ to 8 , and ammonia buffer at $\mathrm{pH} 8.5$ to 10 . Acid solutions were nitric or hydrochloric acids (Merck) at different concentrations prepared by suitable dilution of the respective concentrated acids in deionized water. Solid phase was prepared with dithizone and acetone from Merck, and commercial grade naphthalene.

Synthetic brine was prepared by dissolution of $300 \mathrm{~g}$ of commercial sodium chloride in $1 \mathrm{~L}$ of water. This brine was purified by treatment with $\mathrm{NaOH}$ and $\mathrm{Na}_{2} \mathrm{CO}_{3}$, followed by decantation of $\mathrm{CaCO}_{3}$ and $\mathrm{Mg}(\mathrm{OH})_{2}$ precipitates and acidified with hydrochloric acid.
Apparatus

Atomic emission measurements were made in an ARL ICP OES model 3410 sequential with a mini-torch. The optimized operating parameters are listed in Table 1.

A PROCYON PHD-10 digital $\mathrm{pH}$ meter supplied with a combined glass-calomel electrode was used for $\mathrm{pH}$ measurements.

Table 1. Operating conditions for ICP-OES measurements

\begin{tabular}{lc}
\hline Parameters & $\begin{array}{c}\text { Mini-torch } \\
\text { ICP-OES }\end{array}$ \\
\hline Frequency / MHz & 27.12 \\
Forward power / kW & 0.65 \\
Reflected Power / W & $<10$ \\
Observation height / mm & 12 \\
Nebulizer & Concentric \\
Outer Ar flow / L min-1 & 7.5 \\
Carrier Ar flow / L min & 0.8 \\
Intermediate Ar flow / L min-1 & 0.8 \\
Sample uptake / mL min & -1 \\
Integration time / s & 2.3 \\
\hline
\end{tabular}

\section{Dithizone-naphthalene solid phase preparation}

It was weighed $40.0 \mathrm{~g}$ of naphthalene and $0.40 \mathrm{~g}$ of dithizone that were transferred to a $2 \mathrm{~L}$ vessel containing $850 \mathrm{~mL}$ of acetone. This mixture was stirred for $30 \mathrm{~min}$ with a magnetic stirrer.

Aliquots of this mixture were slowly transferred to a 2 $\mathrm{L}$ vessel with deionized water under stirring. The product from co-crystallization was vacuum filtered using a Bückner funnel and low retention paper. The obtained solid was put in a dessicator with silica gel. This solid phase was stable at least for two months, when kept in a dark well tighted vessel.

\section{Cations extraction and pre-concentration procedure}

Sample volumes from 50 to $200 \mu \mathrm{L}$ containing up to $50 \mu \mathrm{g}$ of each cation were transferred to plastic vessels. It was added $10 \mathrm{~mL}$ of $\mathrm{pH} 8.5$ ammonium buffer solution and $1.5 \mathrm{~g}$ of the solid phase. The vessel was closed and kept under mechanical stirring for $15 \mathrm{~min}$. The mixture was filtered through a filter paper and the liquid phase was discharged. Solid material retained onto filter paper was washed with $15 \mathrm{ml}$ of $8 \mathrm{~mol} \mathrm{~L}^{-1}$ nitric acid. Metals ions extracted were then directly determined by ICP-OES. The same procedure was applied to blanks. An analytical curve prepared in $8 \mathrm{~mol} \mathrm{~L}^{-1}$ nitric acid was used in order to avoid matrix effects. 


\section{Results and Discussion}

In order to obtain quantitative recoveries of metal ions on naphthalene-dithizone solid phase, the separation and pre-concentration procedure were optimized for various experimental parameters such as $\mathrm{pH}$, stirring time, sample volume, amounts of solid phase, sorption capacity and cations desorption from solid phase, by using an univariate approach.

The effect of $\mathrm{pH}$ on simultaneous extraction of the five metal ions was evaluated. Results shown in Figure 1 demonstrated that maximum extraction (over $95 \%$ for all cations) is achieved for $\mathrm{pH}$ ranging from 7.6 to 9.1. In subsequent studies, the $\mathrm{pH}$ was maintained at 8.5 using an ammonium buffer.

In order to determine the best ratio between naphthalene and dithizone amounts for sorption in $100 \mathrm{~mL}$ volume solution, $25 \mu \mathrm{g}$ of each metal ion was added. The proposed pre-concentration procedure was applied and dithizone concentration was tested within the range 0.5 to $3.0 \%$ using $1.0 \mathrm{~g}$ solid phase. Results showed that sorption was quantitative for solid phase using a minimum concentration of $1 \% \mathrm{~m} / \mathrm{v}$ dithizone. After the determination of solid phase composition, $100 \mathrm{~mL}$ volume solution, $25 \mu \mathrm{g}$ of each metal ion, and amounts of solid phase within the range from 0.5 to $2.0 \mathrm{~g}$ were tested keeping constant the concentration of $1 \% \mathrm{~m} / \mathrm{v}$ dithizone. It was found that metal ions recoveries are quantitative over $0.5 \mathrm{~g}$ of $1 \% \mathrm{~m} / \mathrm{v}$ dithizone solid phase. It was recommended $1.0 \mathrm{~g}$ of $1 \% \mathrm{~m} / \mathrm{v}$ dithizone solid phase to guarantee a maximum sorption of the metal ions.

The effect of the reaction time between solid phase and sample was studied by varying the shaking time from 5 to $30 \mathrm{~min}$. All cations had an extraction percentage over 95\%.

The effect of sample volume was studied by varying it from 50 to $500 \mathrm{~mL}$. Obtained results showed that maximum volume must be $200 \mathrm{~mL}$ for an efficiency extraction over
$95 \%$. This stands for a concentration factor up to 13 -fold.

Nitric and hydrochloric acid solutions were tested for back extraction of cadmium, copper, lead, nickel, and zinc from solid phase. Results demonstrated that $15 \mathrm{~mL}$ of 8 mol L $\mathrm{L}^{-1}$ nitric acid can be used for quantitative (>95\%) elution in a single step.

\section{Retention capacity of the adsorbent}

It was assessed the capacity of solid phase to retain each cation in a single element solution. Using different amounts of metal stock solution added to $1.00 \mathrm{~g}$ of solid phase, $10 \mathrm{~mL}$ of $\mathrm{pH} 8.5$ buffer and $100 \mathrm{~mL}$ of deionized water, the efficiency was tested when the metal mass present in different solutions varied in the range 0 to $500 \mu \mathrm{g}$. It was observed that $1.00 \mathrm{~g}$ of solid phase was efficient to retain up to $500 \mu \mathrm{g}$ of each cation when only a single element was present in solution.

Solid phase sorption capacity was also assessed with a multielemental solution. Results showed that $1.00 \mathrm{~g}$ of solid phase was able to retain up to $50 \mu \mathrm{g}$ of each cation adding up to $250 \mu \mathrm{g}$ of total adsorbed cations. It was observed that when each cation is present in amount above $100 \mu \mathrm{g}$, some of them are preferentially retained affecting the retention of the other ones, as shown in Figure 2.

\section{Effect of concomitants}

The effect of $\mathrm{Na}(30 \% \mathrm{~m} / \mathrm{v})$ and $\mathrm{Fe}(500 \mu \mathrm{g})$ on the adsorption of all metal ions (1.0 $\mu \mathrm{g} \mathrm{mL}^{-1}$ of each) on dithizone-naphthalene solid phase was studied only to usual concentrations in brine samples. The tolerance limit was set as the amount of ion required to cause $\pm 3 \%$ error in the determination of $\mathrm{Cd}, \mathrm{Cu}, \mathrm{Pb}, \mathrm{Ni}$, and $\mathrm{Zn}$. Among the elements that could be present at significant levels in highly saline samples, such as $\mathrm{Na}$ and $\mathrm{Fe}$, only Fe interfered.

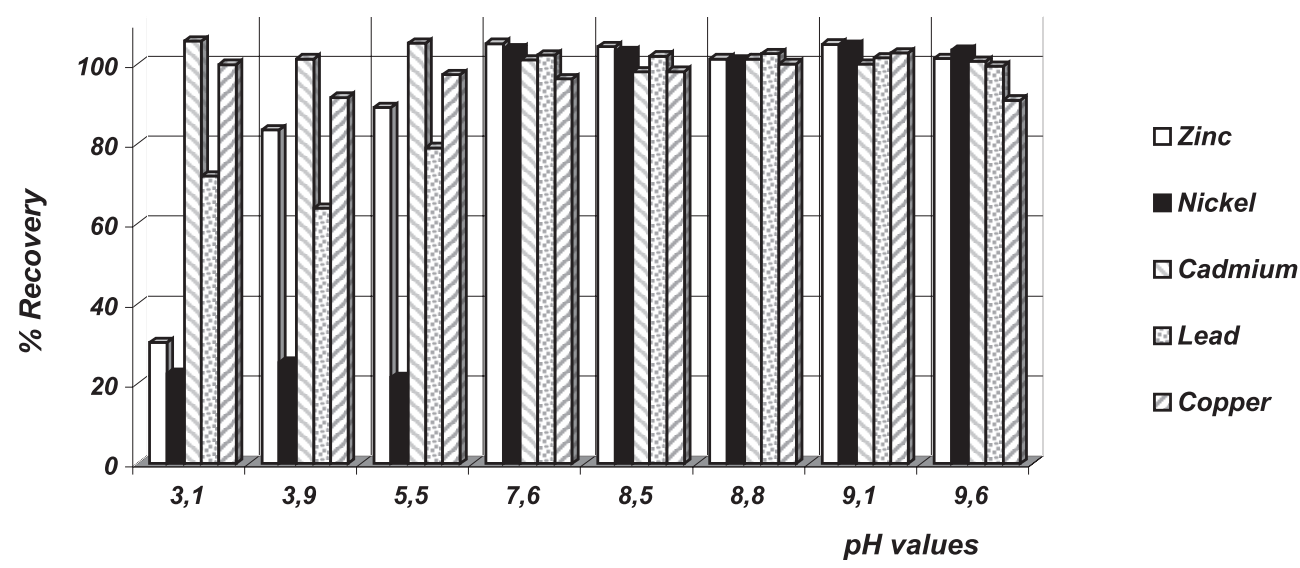

Figure 1. $\mathrm{pH}$ effects on cations extraction by solid phase. Mass of each cation: $25.0 \mu \mathrm{g}$. Sample volume: $100 \mathrm{~mL}$. Phase solid mass: $1 \mathrm{~g}$ with $1 \%$ $(\mathrm{m} / \mathrm{v})$ dithizone. Shaking time: $15 \mathrm{~min}$. Back extraction: 2 extraction with $25.0 \mathrm{~mL} \mathrm{HNO}_{3} 8 \mathrm{~mol} \mathrm{~L}^{-1}$. 


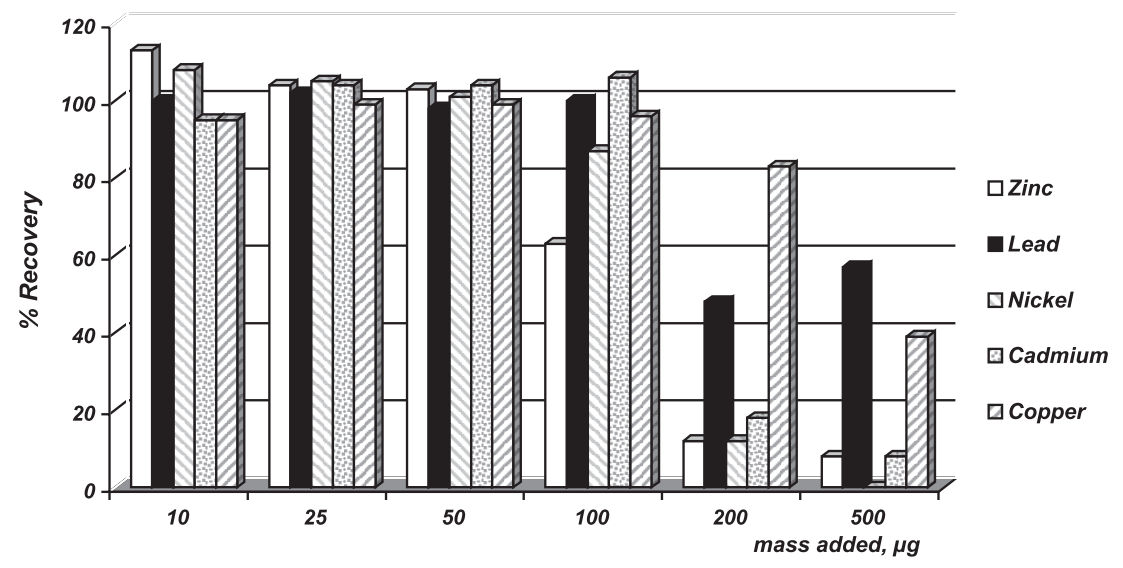

Figure 2. Recoveries percentile of cations on $1.0 \mathrm{~g}$ solid phase with $1 \%$ dithizone. Mass of each metal: 10 to $500 \mathrm{mg}$. Sample volume: $100 \mathrm{~mL}$. Shaking time: 15 min. Back extraction: $25.0 \mathrm{~mL} \mathrm{HNO} 8 \mathrm{~mol} \mathrm{~L}^{-1} \cdot \mathrm{pH} 8.5$.

However, by using $300 \mathrm{mg}$ of citric acid or $300 \mathrm{mg}$ of sodium fluoride or just by increasing the amount of solid phase to $3 \mathrm{~g}$, a mass of $500 \mu \mathrm{g}$ of Fe can be completely masked.

\section{Calibration, sensitivity and precision}

Reference solutions of the elements containing 0.1, $0.5,1.0,2.0$, and $3.0 \mu \mathrm{g} \mathrm{mL}^{-1}$ were prepared from the stock standard monoelement solutions of $\mathrm{Cu}, \mathrm{Pb}, \mathrm{Ni}, \mathrm{Cd}$ and $\mathrm{Zn}$ by dilution with $\mathrm{HNO}_{3} 8 \mathrm{~mol} \mathrm{~L}^{-1}$. The sensitivities found from the slopes of the calibration curves and the correlation coefficients obtained are shown in Table 2. Precision of the method, calculated as relative standard deviations (RSDs) from a set of 10 sample measurements of each cation in a sample with $250 \mu \mathrm{g} \mathrm{L}^{-1}$ of each one was $2.71 \%(\mathrm{Zn}), 2.15 \%(\mathrm{Ni}), 1.53 \%(\mathrm{Cd}), 2.47 \%(\mathrm{~Pb}), 2.78 \%$ $(\mathrm{Cu})$. Table 3 shows BEC (background equivalent concentration) values, detection and quantification limits for $\mathrm{Cu}, \mathrm{Pb}, \mathrm{Ni}, \mathrm{Cd}$, and $\mathrm{Zn}$ ICP-OES determination.

\section{Application}

In order to validate the procedure, spiking was applied in two groups of $100 \mathrm{~mL}$ samples. To the first group was added $10 \mu \mathrm{g}$ of each metal ion before pre-concentration

Table 2. Sensitivities and correlation coefficients of calibration curves

\begin{tabular}{lcc}
\hline Element & $\begin{array}{c}\text { Sensitivity } \\
(\text { Kcounts L mg-1 }\end{array}$ & $\begin{array}{c}\text { Correlation } \\
\text { coefficient }\end{array}$ \\
\hline $\mathrm{Cu}$ & 5.818 & 0.9999 \\
$\mathrm{Ni}$ & 4.000 & 0.9999 \\
$\mathrm{Cd}$ & 10.273 & 0.9997 \\
$\mathrm{~Pb}$ & 0.823 & 0.9999 \\
$\mathrm{Zn}$ & 14.265 & 0.9998 \\
\hline
\end{tabular}

Table 3. BEC values and limits of detection and quantification of the elements by ICP-OES

\begin{tabular}{lcccc}
\hline Metal & $\begin{array}{c}\text { Wavelength } \\
(\mathrm{nm})\end{array}$ & $\begin{array}{c}\mathrm{BEC} \\
\left(\mu \mathrm{g} \mathrm{L}^{-1}\right)\end{array}$ & $\begin{array}{c}\text { Limit of } \\
\text { detection } \\
\left(\mu \mathrm{g} \mathrm{L}^{-1}\right)^{(\mathrm{b})}\end{array}$ & $\begin{array}{c}\text { Limit of } \\
\text { quantification } \\
\left(\mu \mathrm{g} \mathrm{L}^{-1}\right)^{(\mathrm{c})}\end{array}$ \\
\hline $\mathrm{Zn}$ & 213.823 & 53 & 9 & 30 \\
$\mathrm{~Pb}$ & 220.335 & 1144 & 42 & 140 \\
$\mathrm{Ni}$ & 221.633 & 254 & 10 & 34 \\
$\mathrm{Cd}$ & 228.791 & 131 & 5 & 18 \\
$\mathrm{Cu}$ & 324.744 & 487 & 12 & 42 \\
\hline
\end{tabular}

(a) 30 measurements of blanks; (b) 3 times standard deviation of 30 measurements of blank expressed in $\mu \mathrm{g} \mathrm{L}^{-1}$; (c) 10 times standard deviation of 30 measurements of blank expressed in $\mu \mathrm{g} \mathrm{L}^{-1}$.

procedure. To the second group was added $5 \mu \mathrm{g}$ of each metal ion after the pre-concentration procedure. Results in Table 4 showed that both steps, pre-concentration and determination, provided recoveries above $95 \%$ for all samples. The RSDs in all cases were less than $2.8 \%$.

Table 4. Recoveries of $\mathrm{Cd}, \mathrm{Cu}, \mathrm{Ni}, \mathrm{Pb}$ and $\mathrm{Zn}$ from spiked brine samples

\begin{tabular}{|c|c|c|c|c|c|c|}
\hline & \multirow{2}{*}{$\begin{array}{c}\text { Mass of } \\
\text { metals added } \\
(\mu \mathrm{g})\end{array}$} & \multicolumn{5}{|c|}{$\%$ Recovery } \\
\hline & & Zinc & Nickel & Cadmium & Lead & Copper \\
\hline Group $1^{a}$ & 10 & 101.0 & 95.4 & 95.8 & 95.3 & 100.3 \\
\hline Group $2^{b}$ & 5 & 103.2 & 95.1 & 106.2 & 101.8 & 99.8 \\
\hline
\end{tabular}

\footnotetext{
${ }^{a}$ Metals ions added before pre-concentration procedure

${ }^{\mathrm{b}}$ Metals ions added after pre-concentration procedure.
}

The proposed procedure was applied to determine copper, cadmium, zinc, nickel, and lead in synthetic brine sample that contained $300 \mathrm{~g} \mathrm{~L}^{-1}$ of sodium chloride and $250 \mu \mathrm{g} \mathrm{L}^{-1}$ of each cation. Results are shown in Table 5. Good agreement (t-test) was obtained between the added 
and analyte recovered content using experimental procedure. The recovery values calculated for the standard additions were always higher than $95 \%$, confirming the accuracy of the procedure and the absence of matrix effects.

Table 5. Determination of $\mathrm{Cd}, \mathrm{Cu}, \mathrm{Ni}, \mathrm{Pb}$ and $\mathrm{Zn}$ in synthetic brine. Mean and standard deviations $(\mathrm{n}=3)$

\begin{tabular}{lccc}
\hline & $\begin{array}{c}\text { Concentration } \\
\text { of metals added } \\
\left(\mu \mathrm{g} \mathrm{L}^{-1}\right)\end{array}$ & $\begin{array}{c}\text { Concentration } \\
\text { of metals found } \\
\left(\mu \mathrm{g} \mathrm{L}^{-1}\right)\end{array}$ & $\begin{array}{c}\text { Recovery } \\
(\%)\end{array}$ \\
\hline Zinc & 250 & $265 \pm 6$ & 106.0 \\
Nickel & 250 & $248 \pm 3$ & 99.2 \\
Cadmium & 250 & $250 \pm 4$ & 100.0 \\
Lead & 250 & $251 \pm 6$ & 100.2 \\
Copper & 250 & $242 \pm 3$ & 96.8 \\
\hline
\end{tabular}

Solid phase: $1.5 \mathrm{~g}$; Extraction: $25.0 \mathrm{~mL} \mathrm{HNO}_{3} 8 \mathrm{~mol} \mathrm{~L}^{-1}$.

\section{Conclusions}

An efficient adsorbent generated simply by mixing solutions of dithizone and naphthalene has been developed and used for separation and pre-concentration of cadmium, copper, lead, nickel, and zinc in saline matrices. The reagents were easily available and inexpensive. The procedure has the advantage of avoiding organic solvents during extraction step. The recovery of each cation was carried out in a single step by using $15 \mathrm{~mL}$ of nitric acid $8 \mathrm{~mol} \mathrm{~L}^{-1}$. All cations were quantitatively recovered for a sample volume up to $200 \mathrm{~mL}$, which means for a concentration factor of up to 13 -fold.

\section{Acknowledgements}

The authors are grateful to the CNPq (Conselho Nacional de Desenvolvimento Científico e Tecnológico) by financial support and schoolarships provided to M.G.A.K. and A.C.S.C. The authors also express their gratitude to FINEP (Financiadora de Estudos e Projetos), CAPES (Coordenação de Aperfeiçoamento de Pessoal de Nível Superior) and PETROBRAS (Petróleo Brasileiro) for financially supporting this work and Dr. Cristina Coelho for reading of the English manuscript.

\section{References}

1. Boumans, P.W.J.M. In Inductively Coupled Plasma Emission Spectroscopy. Part 1: Methodology, Instrumentation and Performance; Interscience: New York, 1987.

2. Welz, B.; Sperling, M.; Atomic Absorption Spectrometry; VCH: Weinheim, Germany, 1999.

3. Taher, M.A.; Puri, B.K.; Talanta 1996, 43, 247.

4. Taher, M.A.; Analyst 2000, 125, 1865.

5. Taher, M.A.; Talanta 2000, 52, 181.

6. Taher, M.A.; J. Anal. At. Spectrom. 2000, 15, 573.

7. Satake, M.; Ishida, K.; Anal. Chem. 1986, 58, 2502.

8. Satake, M.; Talanta 1992, 39, 1349.

9. Satake, M.; Matsumura, Y.; Mehra, M.C.; Mikrochim. Acta 1980, $1,455$.

10. Ishida, K.; Puri, B.K.; Satake, M.; Talanta 1985, 32, 1985.

11. Nagahiro, T.; Satake, M.; Lin, J.; Puri, B.K.; Analyst 1994, 109,163

12. Mehra, M.C.; Nagahiro, T.; Satake, M.; Mikrochim. J. 1986, 33, 198.

13. Mehra, M.C.; Puri, B.K.; Satake, M.; Analyst 1985, 110, 791.

14. Burns, D.T.; Tungkananuruk, N., Anal. Chim. Acta 1986, 189, 383.

15. Puri, S.; Dubey, R.K.; Puri, B.K.; Hussain, M.F.; Anal. Letters 1998, 31, 283.

16. Ueno, K.; Imamura, T.; Cheng, K. L.; Handbook of Organic Analytical Reagents; CRC Press: London, 1992.

17. Irving, H.M.N.H.; The Analytical Application of Dithizone. Critical Reviews in Analytical Chemistry; CRC PRESS: Boca Raton, 1980, Vol. 8.

18. Sekizuka, Y.; Kojima,T.; Yano, T.; Ueno, K.; Talanta 1973, 20,979.

19. Chwastowska, J.; Kosiarska, M.; Talanta 1998, 35, 439.

Received: July 18, 2001

Published on the web: September 27, 2002 